\title{
Urbanization fueling marriage dynamics among the Baganda of central Uganda
}

\author{
Fredick Ruguma Tumwine ${ }^{1}$ \& James Ntozi ${ }^{2}$ \\ ${ }^{1}$ Department of Geography, Geo-informatics \& Climatic Sciences, \\ Makerere University \\ tumwrug@caes.mak.ac.ug or tumwrug@gmail.com \\ ${ }^{2}$ Department of Population Studies, Makerere University \\ jntozi@bams.mak.ac.ug
}

\begin{abstract}
This paper examines changes in marriage practices and patterns of the Baganda, the largest ethnic group in Uganda. Primary data that included Focus Group Discussions in the rural districts of Mpigi, Kisoro, Sironko and Arua as well as Kampala city that is $100 \%$ urban is complimented with secondary data. The results show that with $18 \%$ of Uganda's population being urban and $5.1 \%$ urban growth rate, marriage practices and patterns have not been spared. It is showed that some relevant marriage practices such as: "pulling"; parent involvement in choosing marriage partners; abstinence before marriage; using traditional items in payment of bride price and rare divorce rates are changing partly because of urbanization. The authors recommend that good Baganda marriage practices and patterns should continue and be strengthened, while polygamy, secret marriages and cohabitation should be discouraged.
\end{abstract}

Key words: Baganda, urbanization, marriage practices and patterns

\section{Introduction}

Urbanization is the process through which the proportion of the country's population that lives in urban areas increases. The urban population in Uganda increased from $6.7 \%$ in 1980 to $9.9 \%$ in $1991,12.3 \%$ in 2002 and $18 \%$ in 2014 . It was also characterized by high growth rate of $5.1 \%$ per annum between 1991 and 2002. Urbanization is associated with modernization and individualism. Modernization as a phenomenon refers to large-scale agricultural manufacturing, infrastructure development, higher per capita wealth and better education. Urbanization breeds a number of complex social problems that arise from shortage of living space and a high cost of living as well as breaking up of joint family system. Thus urbanization can be responsible for destroying the values, culture and principles of society and sometimes lead to other social survival activities such as prostitution (Tumwine and Sengendo, 20I5).

Urbanization is viewed as a dominant factor in fueling changes in marriage practices and patterns among the Baganda tribe in central Uganda. This is Uganda (Tumwine, 2015).

Although it is well recognized that development depends on the family, there has not been much emphasis put on studying family formation and changes in marriage because the Baganda tribe which is about one fifth of Uganda's population lives in central Uganda which is the fastest growing urban region in the country. Apart from Kampala, the capital city of the country, Wakiso district that surrounds it, is home of fast growing urban centers such as Kiira, Nansana, Wakiso Town councils and Entebbe Municipality. The Baganda are also the most spread tribe to other regions of the country compared to the other 56 tribes.

Urbanization is one of the most important geographic phenomena in today's world due to its transformative capacity. The size, density and variety of urban populations tend to have a liberating effect on people, allowing them escape the rigidities of traditional, rural society and to participate in a variety of lifestyles and behavior (Knox and Marston, 2003). With $18 \%$ of Uganda's urban population far reaching implications on development prospects in the country are expected (UBOS, 2014). Marriage practices are not exceptions. This is because urbanization emphasizes the economic aspects of patterns such as cohabitation and secret marriages in Uganda. This study emphasizes that development programs should be family centered. A husband and wife form very 
good development partners. Urbanization emphasizes the economic aspects of marriage rather than the social ones.

\section{Objective of the paper}

The paper examines the influence of urbanization on marriage practices and patterns of Baganda, such as "pulling", sex abstinence before marriage, payment of bride price, divorce, secret marriage, cohabitation, polygamy, age at marriage and mixed marriages.

\section{The data sources and research methods}

The data in this paper is derived from a wider comparative study based on primary data collected in 2004 survey using a questionnaire and Focus Group Discussions (FGDs) that covered Kampala City whose boundaries overlapped those of Kampala district and four rural districts that represented the four regions of Uganda (Maps I and 2). Kampala was chosen because of a number of reasons. It is the largest urban area of Uganda in terms of population and size. It is the capital city of Uganda. Kampala remained the prime urban center throughout the period 1969-20I4. The proportion of the population of Kampala city to the total urban population of Uganda has been high, although declining from $54 \%$ in $1969,41 \%$ in $1991,40 \%$ in 2002 to $25 \%$ in 2014. The city was therefore seen as the most representative of urban areas. Being a capital city and the most cosmopolitan urban area, all the ethnic groups in the study could be found in big numbers.

Map I: Map of Kampala showing the study areas.

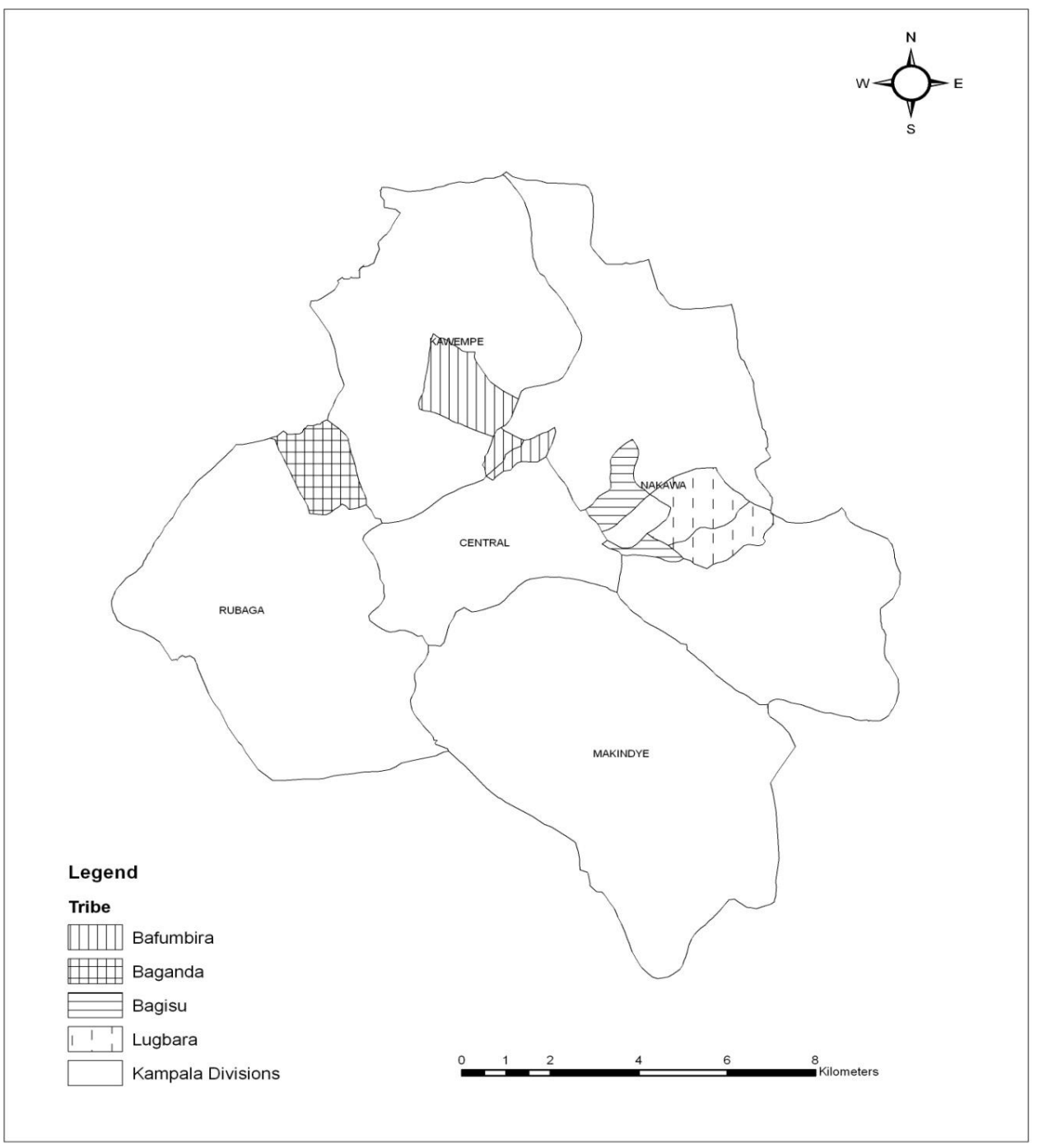

Source: Fieldwork by the Researcher

Four ethnic groups namely: Baganda, Bagisu, Lugbara and Bafumbira were studied. Each of the four ethnic groups represented one of the four regions of the country namely: Baganda (Central), Bagisu (Eastern), Lugbara (Northern) and Bafumbira for Western Uganda. In order to establish the changes in marriage patterns as a result of urbanization, four rural areas in four districts of Uganda where the four ethnic groups originate were also covered. These included: Mpigi (Central), Sironko (Eastern), Arua (Northern) and Kisoro (Western) as observed from Map 2. This made it possible to compare marriage practices and patterns of the four tribes in rural and urban areas of the country. 
With the aid of a questionnaire, primary data was obtained from all persons aged 15 years and above found in households from each of the ethnic groups qualified for interview. Age 15 was chosen because it is the one used to calculate singulate mean age at first marriage using Hajnal (1953) formula, which assumes that no first marriages occur before age 15 .

Judgmental (purposive) sampling was used to get four ethnic groups for the study. According to Kitchin and Tate, (2000), judgmental sample is the most subjective sampling method. Here, sample elements are selected based on judgment derived from prior experience. Sampling elements are selected based on the interviewer's experience that they are likely to produce the required results. The Bafumbira, Bagisu, and Lugbara who come from different regions of Uganda are known to be concentrated in some areas of Kampala. It was therefore easy to find a good number of each ethnic group in Kampala to be used to compare with those who have remained in the ethnic districts of the selected tribes of Uganda. The Baganda on the other hand, comprise the biggest single ethnic group in Kampala and central region as a whole.

Map 2: Location of the study districts in Uganda.

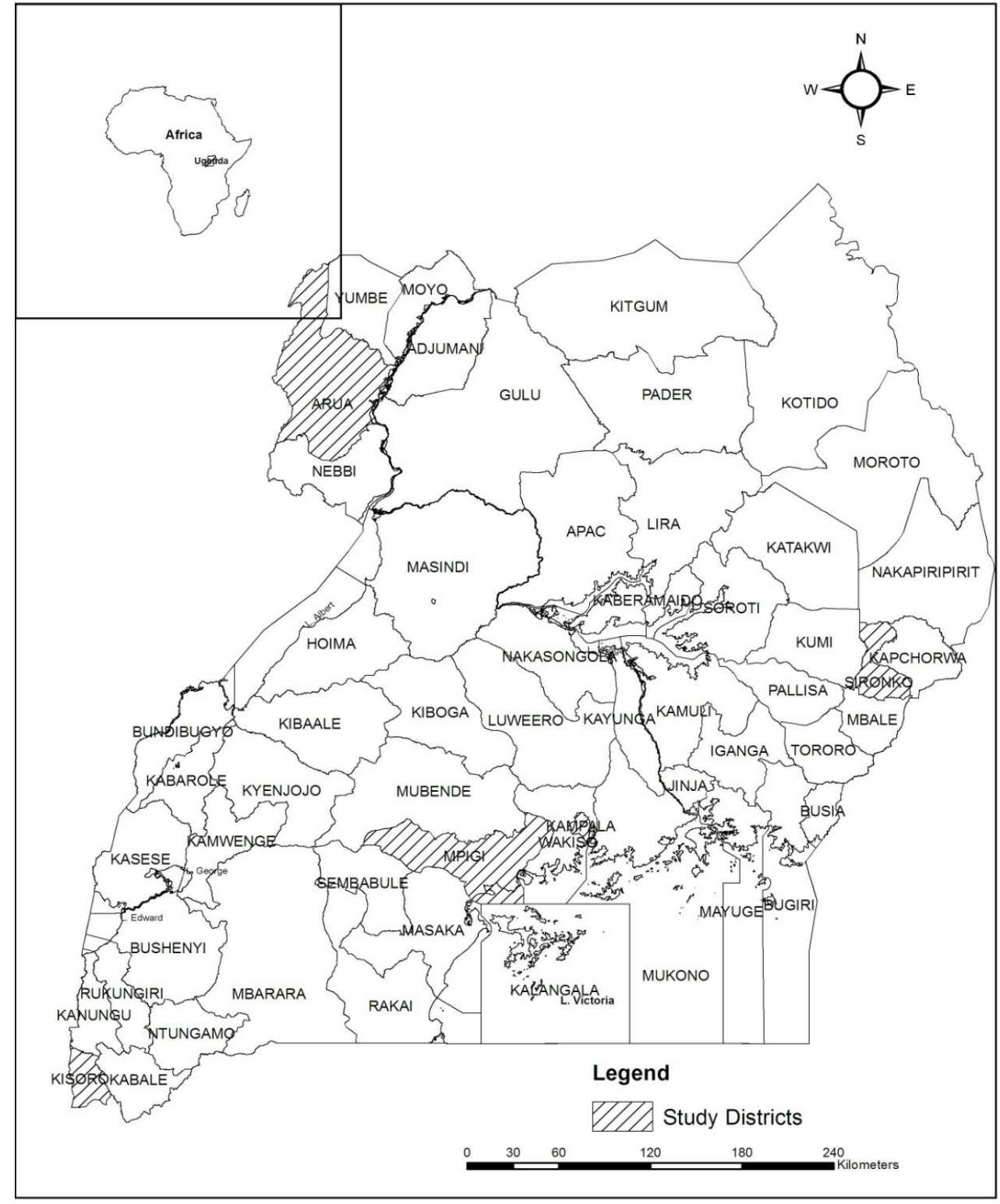

Source: Population and Housing Census Map. 2002

Snowball sampling was used to get respondents in urban areas. Snowball sampling is non-random sampling method, which is used with the selection of people. This is based on a number of initial contacts that are asked for names and locations of any other http://aps.journals.ac.za people who might fulfill the sampling requirements. For example, the respondents interviewed would help to inform the interviewers the location of their fellow members of the same tribe. The Baganda would help to locate fellow Baganda and so would 
the Lugbara, Bagisu and Bafumbira. Snowball sampling was effective because, even Kifumbira in Kamwokya, which is a well known area of residence of the Bafumbira in Kampala, is also occupied by other tribes. The sampling method also helped in getting cases of inter-tribal marriages.

In the rural areas, systematic sampling was applied. Using household lists of the villages provided by the Local Council (LC) officials, even numbered households were selected. After securing a Local Council (LC) official as a guide, the group (principal investigator, two interviewers and the LC official) moved around, interviewing all the members of the households aged 15 years and above. To make sure that all the eligible members were interviewed, those who were not found at home would be followed where they were working for example in the gardens. This was easy in the rural areas where $59 \%$ of the respondents were farmers. A total number of 1683 respondents were available for the interview. These included 833 respondents ( 441 males and 392 females) from the rural areas and 850 respondents (4I8 males and 432 females) from the urban area (Kampala city). The Baganda were 24.2\% (24.8\% and $23.5 \%$ for rural and urban respectively) of the total respondents.

Focus Group Discussions (FGDs) using an interview guide facilitated the acquisition of detailed information on indigenous marriage patterns among the tribes. The FGDs complimented the survey that covered four tribes in Uganda namely: Bagisu, Baganda, Lugbara and Bafumbira in the districts of Sironko, Mpigi, Arua and Kisoro. Sixteen FGDs i.e. eight from Kampala and eight from the rural areas were used. This was because, in order to get good information from the groups, men had to be separated from the women. Therefore, for each of the four tribes there were four FGDs: two separate ones for men and women for each tribe in Kampala and also two in the rural areas. It was strongly believed that women would be too shy to talk about sensitive marriage issues in the presence of men. Each of the FGDs was comprised of between 8 and 12 men and women above 18 years. In selecting the people to participate in the discussions the following characteristics were considered: age; religion; level of education and occupation. This was meant to avoid getting a whole group of people of similar characteristics.

Secondary data sources such as Uganda Population and Housing Census results (UPHC) of 1980, 199I, 2002 and 20I4; and Uganda Demographic Healthy Surveys (UDHS) of 1988/89, 1995, 2000/0I, 2006 and 20II were used to supplement the quantitative data obtained from the questionnaire and the qualitative data from the FGDs.
In the analysis of data, the Chi-Square statistic was used to determine whether there were any significant associations between the dependent variables (i.e. cohabitation, secret marriage, polygamy, age at marriage, mixed marriages and marital status) and independent variables (area of residence, religion, education, tribe and occupation). Associations were considered significant at $p<0.05$.

Logistic regression as a multivariate analysis was used to test the effect of the independent variables ((tribe (Baganda) and area of residence (urban)) on the dependent variables (cohabitation, secret marriage, polygamy, age at marriage and intermarriage)

\section{Traditional marriage of the Baganda}

In this section, we look at the stages that two families were involved in from the choice of the marriage partners to the actual marriage and thirty days after the consummation of marriage. As far as marriage in the past was concerned, it was the parents who initiated and conducted the marriage arrangements for their children. A man could not marry from his own clan except for the members of the "mamba" and "ngabi" clans. They gave the justification that they were very many. The justification of these clans was upheld by Kabaka Muwenda Mutebi in 2006, when the mamba clan was split into "mamba kakoboza" and "mamba gabunga". The ngabi clan was split into "ngabienyunga" and "ngabinsamba". Even then marriages occurred between distant clan members and not close relatives.

Marriage was very important in Buganda. An unmarried person received no respect in the eyes of society. Dying or being unmarried after one had passed marriageable age was considered a curse. It was worse for spinsters who were considered witches, night dancers and prostitutes. The dead body of any man who died before he could get married was never passed through the main door of the house. A hole was made in one of the walls where the dead would be passed for burial. Thus, every Muganda man or woman regarded marriage as a very important aspect in his/ her life. Forced marriage existed among the Baganda. Parents chose marriage partners for their children. There was no way a boy or a girl would refuse to get married to anybody the parents had decided for him or her. Marriage was according to order of birth in the family. A younger girl would not get married before her elder sister ("omuto tafumbirwa n'alekamukuluwe kuluggya").

The parents did the process of choosing the right spouse. They had to scrutinize families for potential spouses until they landed on the right family. That family had to be free of the feared diseases like 
tuberculosis, epilepsy (fits) and mental illness. Undesirable habits were also considered. Families of those who were assumed to be night dancers, witches, thieves and womanizers were avoided. There was fear that those nasty habits would be reborn in the children so it was important that both parents were blameless. The family of the spouse had to belong to a different clan, both on the maternal and paternal side. This was to avoid incest. Children of divorced mothers were avoided lest they pass on the habit to the children and grandchildren. Lastly, beauty was also considered because no one wanted to produce ugly children.

After clearing the family issue, wooing ("okwogesereza") would start. The first step was the boy's mother approaching the girl's mother to discuss all the important issues about their children. This was a top-secret affair, strictly between the two parents. Even the children concerned were not supposed to know to avoid embarrassment in case of one side objected.

After the approval on both sides, there would be the first visit ("okukyala okusoka").

The father, the bridegroom-to-be, and other people were involved in the visit. This was followed by taking of presents ("ebirabo"). The presents included bark cloth ("olubugo"), meat ("enyama") and salt ("omunyo"). The prospective bridegroom team would be served with coffee beans ("emmwanyi") as a sign of lasting relationship between the two families.

After a few days the father of the groom-to-be with other people would return to the home of the bride-to-be carrying two big calabashes of alcohol ("ebitabyomwenge bibiri"). They would be informed about the bride price to be paid. Bride wealth included barkcloth ("olubugo"), meat, salt and other food items. The presents would be taken in baskets ("ebibbo"). Many people on the boy's side contributed to the payment of bride price. These included relatives of the boy on the father's and mother's sides. On the day the bride price would be paid, the date of marriage would be fixed.

On the wedding day, there would be a party at the bride's home. This was a day for advice to the bride. The bride would be told to listen and obey her husband and in-laws. She was counseled never to quarrel with the husband and never to greet her husband and in-laws without kneeling. It would also be emphasized to her never to return home without permission of the husband. Traditionally, there was no divorce among the Baganda.

Before the girl would be escorted to her husbandto be's home, a number of items representing what was spent at night looking after the girl getting married would be presented to her home. These items were referred to as: "kasuzekatya". They included: paraffin ("amafuta"); match box ("ekibiriti"); funnel; and pick can ("akahujo"). On the wedding day, the girl would be escorted by a number of people ("emperekeze").

The bride was taken during the day. If the girl was a virgin, she would be escorted by her paternal aunt ("ssenga").

When the entourage arrived at the groom's home, the bride would kneel on a mat.

A relative of the bride would get her hand and deliver her to the groom. The sister of the groom would take the bride to the house. The hen for the brother of the girl ("omuko") and the bark cloth for the paternal aunt ("ssenga") would be handed to them. Coffee beans would be served. The other people would return home that day but the aunt would remain. The purpose of the aunt would be to take the beddings and a goat that had never had sexual relations with a he-goat if the bride was found a virgin. Virginity was highly emphasized in traditional culture of the Baganda. On her way out, she would pass by the rear door of the house. On reaching home, the goat would be slaughtered and eaten without salt. If the bride was found not to be a virgin, the aunt would shamefully depart empty handed.

The end of the honey moon ("okuggyaomugole mu kisenge") was performed by the mother-in-law and other relatives of the groom. Food which included mushroom soup, would be cooked and the bride would eat with them. Thereafter, she would start performing household chores. This was after seven days.

After thirty days the paternal aunt and relatives of the bride would go and visit the bride. This was meant to bless the marriage ("okuggyaomuzigo mu kkubo"). The delegation would carry with them the following items: bananas; simsim: mushrooms and salt. They never spent a night there.

\section{Changes in marriage patterns of the Baganda as a result of urbanization \\ Cultural practices}

The cultural practice of "pulling" or stretching a woman's labia minora (the inner lobes of the vagina just below the clitoris) that is highly cherished by the Baganda is threatened by urbanization. The cultural practice is referred to as visiting the bush ("Okukyaliraensiiko"). This is because traditionally, a group of girls used to be taken to the bush by an old woman for about a week and taught how to pull. After that, the girls were advised to continue pulling on their own. This was because the longer the time the pulling is done the better the results. Informants in the focus group discussions of the Baganda were asked whether they considered "pulling" to be 
important in marriage. All the groups both rural and urban areas highly praised the practice. This agrees with Tumwine (2015) that elongation of the labia minora ("pulling") is a common practice among the Baganda in central region and some tribes in western Uganda. The main reason given in support of the cultural practice was that it makes sex more enjoyable. It makes sexual arousal and satisfaction faster because the clitoris, the most sensitive part of the vagina, is connected to the labia, so, the long labia helps the woman to reach orgasm quickly. However, the practice of "pulling" has now changed in the urban areas in that it is not done in the bush as was formerly the case. There are no bushes in the urban area. The paternal aunts and mothers teach the young girls to do it at home. The queen mother of Buganda ("Nabagereka") organizes all round teaching and instructions ("Ebisaakate") to girls of different ages and "pulling" is one of the items. On the other hand, there are commercial people who even include men that claim that they help women improve their sexual lives and "pulling" is one of the items (Nagawa, 20I5).

Secondly, in the past, parents used to arrange marriages for their children. This practice shows the social importance of marriage, especially as it concerns the families and relatives of the couple. Tumwine (2007) reports that the parents chose the right spouse for their children. They had to scrutinize families for potential spouses until they landed on the right one. That family had to be free of the feared diseases like tuberculosis, epilepsy and mental illness. Undesirable habits were also considered. Families of night dancers, witches, thieves and womanizers were avoided. There was fear that those nasty habits would be re-born in the children so it was important that both parents were blameless. Findings indicate that this has greatly changed. Makinwa-Adebusoye (200I) observes that traditional African family patterns are slowly but progressively being altered as a result of the process of modernization which is exhibited through trends like urbanization. In traditional rural African societies, contraction of marriage was dominated by arranged marriages whereby parents usually indulged in the selection of marriage partners for their children.
Thirdly, bride price refers to payment in form of money, property or other valuable assets by the family of the bridegroom-to-be to the family of his bride-to-be. Traditionally, in the culture of the Baganda, bride-price was regarded as thanks giving to the parents of the bride. Apart from the one main specified gift given to the parents in appreciation of upbringing the bride commonly known as "omutwalo"; two big calabashes of alcohol; "kanzu" for the father, "gomesi" for the mother and paternal aunt; salt and meat, other items were optional. The family of the groom brought items that it could afford. These included food items such as bananas, vegetables, tomatoes, pumpkins, chicken, goats and fruits such as vacados, jack fruits. Bride price also included clothes ("gomesi" and "Kanzus") for other close family members such as aunts and uncles. The general observation is that to-day, money is preferred to the traditional physical items such as animals, clothing and food. A number of parents have gone to the extent of demanding for even more expensive items such as cars. Figure I shows that some of the traditional items for bride price in Buganda are extravagantly decorated and provided in big quantities making the practice more expensive. This is in agreement with Yasuko and Kao- Lee (1997) who noted that bride-price originally took the form of tangible goods like livestock. However, it has increasingly been replaced by cash. Focus group discussions were of the view that the increase in the items and cash paid is due to showing off of people. Urban respondents in the Baganda group said: "Of recent, parents of the girls are demanding for a lot of money. Bride price is no longer a token of appreciation but a source of wealth". Members were of the view that parents should try as much as possible to stick to the traditional symbolic items that were regarded as signs of appreciation to the parents of the bride. Expensive items such as cars, fridges, washing machines and sofa sets should be discouraged. Members stressed that people should avoid taking payment of bride price as a ceremony of showing off the wealth of the groom family. 
Figure 1: A display of some bride price items on a traditional ceremony in Buganda

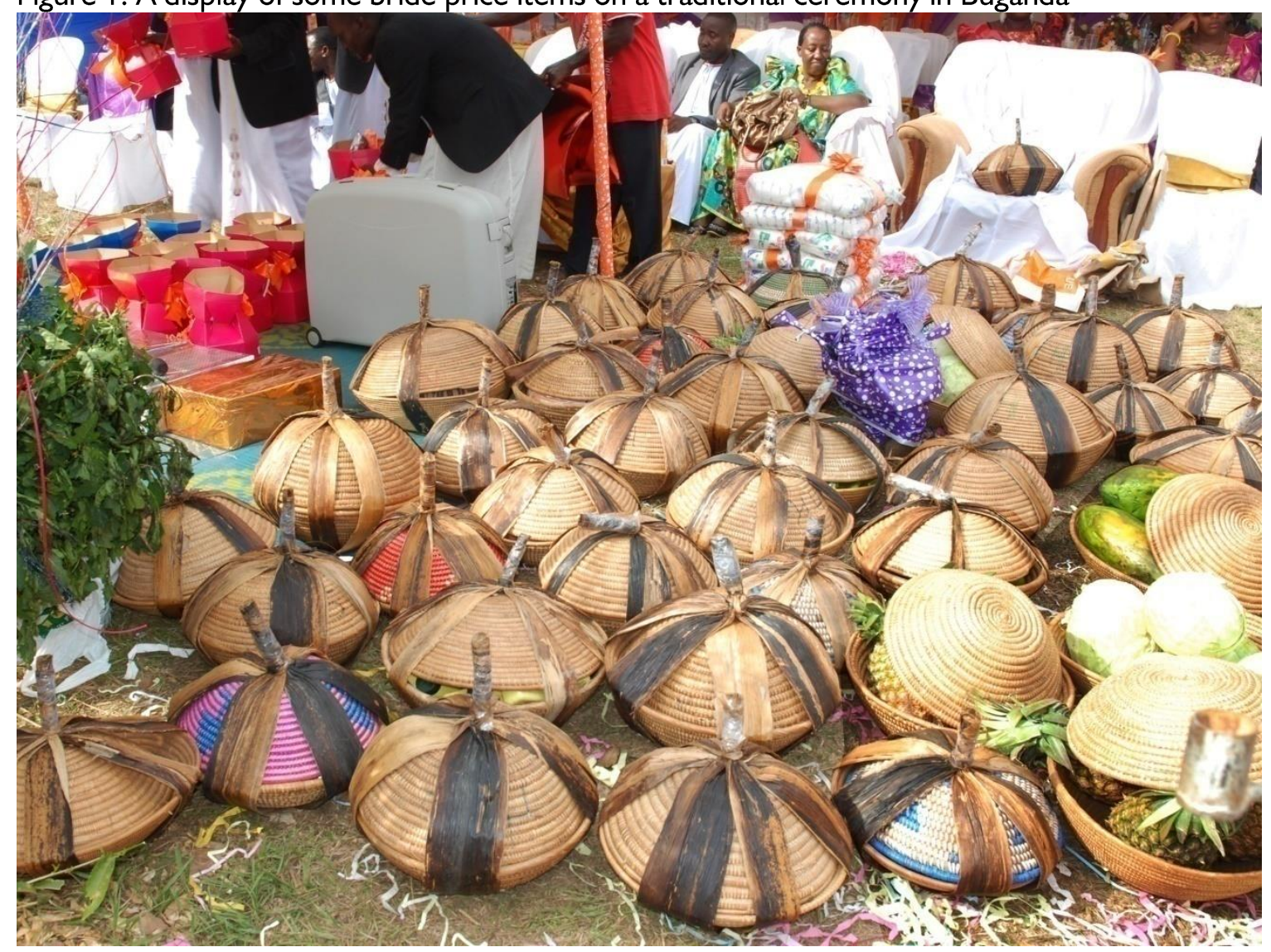

Divorce is one of the indicators of marital instability. It is a legal dissolution of an established family. It appears to be increasing as well. The Baganda respondents in the focus group discussions indicated divorce is increasing as a result of modernization that has contributed to the following: Failure to understand each other leading to fighting and quarreling; lack of patience ("obuguminkiriza"), disrespect by women as a result of women emancipation (“ömwenkanonkano"); adultery ("okwenda"); lack of sexual satisfaction ("obutamatiramukwano") due to heavy alcohol consumption that increases interest in sex but reduces performance of the man.

Tumwine (2015) observes that divorce has increased due to the following reasons: Lack of patience and disrespect by women as a result of women emancipation. The respondents were of the view that women who regard themselves as liberated and independent do whatever they want. Whereas in the past, a woman knew that a man was supreme. To-day, women are more involved in family decision making, pursuing their own needs and interests. They expect their husbands to share in the household chores such as childrearing responsibilities. With more economic power and slightly better laws in place, women are increasingly dragging their husbands to courts of law due to mistreatment.
Women can own or buy land and other property and can therefore fend for themselves after divorce.

Poverty, which includes the failure of the husband meeting simple needs of their wives and failure to pay bride price was yet another leading cause of divorce. It was emphasized that until all the bride price is paid the bride is not fully regarded as one's wife. However, after it has been paid the woman is discouraged as much as possible not to divorce since the man has the right to claim the bride price from her kin. Related to poverty, is alcoholism. Tumwine and Mwebaze (2016) show that excessive consumption of alcoholic drinks is a major cause of poverty in terms of the amount of money spent on it and its effects. Large numbers of chronically poor households and those that later fell into poverty devoted more than one quarter of their household's budget to purchases of alcoholic drinks. In addition, alcohol deprives the partner of the company and comfort because the partner is always away from home. Baganda women FG in Kampala said: "alcohol increases interest in sex yet it reduces performance of the man".

Table 2 shows causes of divorce were viewed differently according to urban and rural respondents. The main causes of divorce in urban areas included adultery $(25 \%)$ and failure to understand each other (25\%). With the HIV/AIDS scare, adultery cannot be taken lightly. The most common mode of HIV 
transmission is sexual contact. Men and women with multiple sexual partners are among the groups with the highest risk of sexual transmission. Therefore, mutual fidelity as well as limiting the number of sexual partners are some of the most effective preventive behaviors of HIV infection. Adultery is therefore, a cause of worry because of the AIDS pandemic.
Husbands need to consider the views of their wives and vise versa. This is because without consulting each other one will not be able to know the needs and interests of the partner (Tumwine, 20I5). Table I summarises the causes of divorce in rural and urban areas.

Table I: Percentage distribution of the causes of divorce according to sex and area of residence.

\begin{tabular}{|c|c|c|c|c|c|c|}
\hline \multirow{2}{*}{$\begin{array}{l}\text { Rural areas } \\
\text { Reason }\end{array}$} & \multicolumn{2}{|c|}{ Male } & \multicolumn{2}{|c|}{ Female } & \multicolumn{2}{|c|}{ Total } \\
\hline & $\mathbf{N}$ & $\%$ & $\mathbf{N}$ & $\%$ & $\mathbf{N}$ & $\%$ \\
\hline Failure to understand each other & 9 & 42.9 & 4 & 20.0 & $|33|$ & \\
\hline Partner hash / mistreatment & 1 & 4.8 & 7 & 35.0 & 8 & 19.5 \\
\hline Poverty. Not buying necessities /no bride price & 4 & 19.0 & 2 & 10.0 & 614 & \\
\hline Adultery & 2 & 9.5 & 2 & 10.0 & 4 & 9.8 \\
\hline Barrenness/ impotence & 1 & 4.8 & 2 & 10.0 & 3 & 7.3 \\
\hline Partner married another wife & 0 & 0.0 & 3 & 15.0 & 3 & 7.3 \\
\hline Wife failed to cope with partner's relatives & 2 & 9.5 & 0 & 0.0 & 24. & \\
\hline Wife aborted & 1 & 4.8 & 0 & 0.0 & 1 & 2.4 \\
\hline Alcoholism & I & 4.8 & 0 & 0.0 & 1 & 2.4 \\
\hline Total & 21 & 100.0 & 20 & 100.0 & 41 & 100.0 \\
\hline \multicolumn{7}{|l|}{ Urban areas } \\
\hline Adultery & 2 & 13.3 & 10 & 30.312 & 25.0 & \\
\hline Failure to understand each other & 8 & 53.3 & 4 & 12.112 & 25.0 & \\
\hline Poverty. Not buying necessities /no bride price & 3 & 2.0 & 5 & 15.28 & 16.7 & \\
\hline Partner hash / mistreatment & 0 & 0.0 & 6 & 18.26 & 12.5 & \\
\hline Alcoholism & 0 & 0.0 & 4 & 12.14 & 8.3 & \\
\hline Partner married another wife & 0 & 0.0 & 3 & 9.13 & 6. & .3 \\
\hline Wife aborted & 1 & 6.7 & 0 & 0.01 & 2. & .1 \\
\hline Barrenness/ impotence & 1 & 6.7 & 0 & 0.01 & 2. & .1 \\
\hline Wife failed to cope with partner's relatives & 0 & 0.0 & 1 & 3.01 & 2.1 & \\
\hline Total & 15 & 100.0 & 33 & 100.0 & 48 & 100.0 \\
\hline
\end{tabular}

Source: Tumwine (2015)

Results and discussion of influence of urbanization on marriage patterns of the Baganda

\section{Cohabitation}

In Uganda, co-habitation is understood in different ways. First, it is known as an informal union in which a man and woman stay together intending to have a lasting relationship, even if a formal civil or religious ceremony has not occurred. It is also referred to as "living together" (UDHS, 1995). Further, it is known as consensual union, that is, marriage that exists simply because the parties to the marriage have agreed to live together (UBOS, 2006). Byamukama (2006) clarifies that co-habitation is a type of marriage where a man and a woman decide to live together without complying with legal requirements. In addition, co-habitation is regarded as the beginning of other types of marriages: Civil (marriage contracted before an official Government registrar under the Registrar General); Religious (marriage performed by one of the recognized religions in the country in a recognized place) and Customary (marriage contracted between two families through the performance of marriage rites as required by a particular culture within which the marriage is taking place).

Cohabiting couples were those who admitted that they were married yet their marriage was not 
religious, civil nor customary. Table 2 reveals that the and $54 \%$ urban), followed by those who were never married (25\% rural and $32 \%$ urban), cohabiting ( $4 \%$ rural and $8 \%$ urban) widowed (5\% rural and $4 \%$ urban) and separated/divorced (4\% rural and 5\% urban).

Co-habitation appeared to be more popular with urban respondents $(7 \%)$ compared with $3 \%$ for the rural respondents (Table 2). This was attributed to majority of the respondents were married (67\% rural economic situation that is hindering formal marriage. Most young women always aspire to marry men of more economic means than themselves so as to ensure that their children are not born in poverty. Conversely, men of low incomes tend to fear marrying women with high incomes so as to avoid to be dominated by women (Tumwine, 2007).

Table 2: Marital status by sex and residence

\begin{tabular}{|c|c|c|c|c|c|c|}
\hline \multirow{3}{*}{$\begin{array}{l}\text { Males } \\
\text { Marital status }\end{array}$} & \multicolumn{4}{|c|}{ Area of residence } & \multirow{2}{*}{\multicolumn{2}{|c|}{ Total }} \\
\hline & \multicolumn{2}{|l|}{ Rural } & \multicolumn{2}{|c|}{ Urban } & & \\
\hline & $N$ & $\%$ & $\mathbf{N}$ & $\%$ & $N$ & $\%$ \\
\hline Never married & 112 & 25.4 & 135 & 32.3 & 247 & 28.8 \\
\hline Married & 294 & 66.7 & 236 & 56.5 & 530 & 61.7 \\
\hline Widowed & 7 & 1.6 & 5 & 1.2 & 12 & 1.4 \\
\hline Separated/div & 11 & 2.5 & 9 & 2.2 & 20 & 2.3 \\
\hline Cohabiting & 17 & 3.9 & 33 & 7.9 & 50 & 5.8 \\
\hline Total & 441 & 100.0 & 418 & 100.0 & 859 & 100.0 \\
\hline \multicolumn{7}{|c|}{ Chi-square $=13.536, p=0.009$} \\
\hline \multicolumn{7}{|c|}{ Females } \\
\hline Never married & 67 & 17.1 & 115 & 26.6 & 182 & 22.1 \\
\hline Married & 259 & 66.1 & 225 & 52.1 & 484 & 58.7 \\
\hline Widowed & 34 & 8.7 & 32 & 7.4 & 66 & 8.0 \\
\hline Separated/div & 24 & 6.1 & 34 & 7.9 & 58 & 7.0 \\
\hline Cohabiting & 8 & 2.0 & 26 & 6.0 & 34 & 4.1 \\
\hline Total & 392 & 100.0 & 432 & 100.0 & 824 & 100.0 \\
\hline \multicolumn{7}{|c|}{ Chi-square $=13.536, p=0.009$} \\
\hline \multicolumn{7}{|c|}{ Both sexes } \\
\hline Never married & 179 & 21.5 & 250 & 29.4 & 429 & 25.5 \\
\hline Married & 553 & 66.4 & 461 & 1014 & 60.2 & \\
\hline Widowed & 41 & 4.9 & 37 & 4.4 & 78 & 4.6 \\
\hline Separated/div & 35 & 4.2 & 43 & 5.1 & 78 & 4.6 \\
\hline Cohabiting & 25 & 3.0 & 59 & 6.9 & 84 & 5.0 \\
\hline Total & 833 & 100.0 & 850 & 100.0 & 1683 & 100.0 \\
\hline Chi-square $=3$ & $p=0.0$ & & & & & \\
\hline
\end{tabular}

Respondents who were married in church or mosque were asked whether they had started their marriage by co-habiting or not. Table 3 , shows that $15.6 \%$ of the respondents married in church or mosque (religious marriages) started by co-habiting. The percentage of respondents who co-habited before formal marriage was higher in urban areas (23.9\%) than rural areas (8.5\%). Results of the Chi-square test reveal that area of residence is significantly associated with co-habitation $(p=0.000)$. Therefore, urbanization plays a significant impact on cohabitation. 
Table 3: Co-habitation by sex and residence

\begin{tabular}{|c|c|c|c|c|c|c|}
\hline \multirow[t]{2}{*}{ Males } & \multicolumn{2}{|l|}{ Rural } & \multicolumn{2}{|l|}{ Urban } & \multicolumn{2}{|c|}{ Total } \\
\hline & $\mathbf{N}$ & $\%$ & $\mathbf{N}$ & $\%$ & $\mathrm{~N}$ & $\%$ \\
\hline Cohabited & 26 & 9.0 & 49 & 21.2 & 75 & 14.4 \\
\hline Never cohabited & 263 & 91.0 & 182 & 78.8 & 445 & 85.6 \\
\hline Total & 289 & 100.0 & 231 & 100.0 & 521 & 100.0 \\
\hline \multicolumn{7}{|c|}{ Chi-square $=|5.52|, p=0.000$} \\
\hline \multicolumn{7}{|c|}{ Females } \\
\hline Cohabited & 23 & 8.0 & 69 & 26.2 & 92 & 16.7 \\
\hline Never cohabited & 265 & 92.0 & 194 & 73.8 & 459 & 83.3 \\
\hline Total & 288 & 100.0 & 263 & 100.0 & 551 & 100.0 \\
\hline \multicolumn{7}{|c|}{ Chi-square $=32.916, p=0.000$} \\
\hline \multicolumn{7}{|l|}{ Both sexes } \\
\hline Cohabited & 49 & 8.5 & 118 & 23.9 & 167 & 15.6 \\
\hline Never cohabited & 528 & 91.5 & 376 & 76.1 & 904 & 84.4 \\
\hline Total & 577 & 100.0 & 494 & 100.0 & $107 \mid$ & 100.0 \\
\hline
\end{tabular}

The binary logistic regression model was used to assess the impact of selected variables on cohabitation, since the dependant variable was dichotomous. In the model, co-habited was assigned $I$ and never co-habited 0 . The results are summarized in Table 4. The multivariate analysis found area of residence, tribe and occupation to be significant factors in affecting co-habitation. The results of the analysis show that respondents in urban areas were 2 times $(O R=2.1)$ more likely to have co-habited before formal marriage than their rural counterparts. Urbanization as area of residence was the second most significant factor influencing co-habitation with a $p=0.002$. For example, some urban respondents could still stay with their partners despite the rejection by the parents. This is because urbanization creates independence and reduces communal dependence of married couples on their parents. It should be noted that co-habitation undermines the cultural importance of virginity before formal marriage. Virginity encouraged abstinence before marriage. Baganda elders said: "Parents are interested in church marriages and always expect their daughters to be virgins before marriage".

Table 4: Results of logistic regression analysis of selected variables on co-habitation

\begin{tabular}{|c|c|c|c|c|c|c|}
\hline \multicolumn{2}{|l|}{ Variables } & \multirow{2}{*}{$\begin{array}{l}-4.109 \\
-4\end{array}$} & \multirow[t]{2}{*}{ Odds ratios } & \multirow{2}{*}{$\begin{array}{l}\text { Std. Error } \\
.452 \\
\end{array}$} & \multirow{2}{*}{\begin{tabular}{|l|} 
Wald \\
82.464 \\
\end{tabular}} & \multirow{2}{*}{$\begin{array}{l}\text { p-value } \\
.000\end{array}$} \\
\hline & Intercept & & & & & \\
\hline \multirow[t]{2}{*}{ Residence } & Urban & .749 & 2.114 & .238 & 9.866 & .002 \\
\hline & Rural \# & 0.000 & 1.000 & & & \\
\hline \multirow[t]{3}{*}{ Religion } & Protestant & -.023 & .977 & .206 & .013 & .910 \\
\hline & Moslem & .240 & 1.271 & .285 & .707 & .400 \\
\hline & Catholic \# & 0.000 & 1.000 & & & \\
\hline \multirow[t]{3}{*}{ Education } & Primary & .326 & 1.385 & .413 & .623 & .430 \\
\hline & Secondary & .718 & 2.050 & .424 & 2.862 & .091 \\
\hline & Tertiary & .814 & 2.258 & .481 & 2.870 & .090 \\
\hline
\end{tabular}




\begin{tabular}{|c|c|c|c|c|c|c|}
\hline & None\# & 0.000 & 1.000 & & & \\
\hline \multirow[t]{4}{*}{ Tribe } & Baganda & 1.598 & 4.944 & .305 & $27.44 I$ & .000 \\
\hline & Bagisu & .990 & 2.690 & .335 & 8.710 & .003 \\
\hline & Lugbara & 1.125 & 3.081 & .304 & 13.713 & .000 \\
\hline & Bafumbira \# & 0.000 & 1.000 & & & \\
\hline \multirow[t]{4}{*}{ Occupation } & Professional & .560 & 1.750 & .365 & 2.347 & .126 \\
\hline & Other & .716 & 2.047 & .320 & 5.022 & .025 \\
\hline & Trader & .518 & 1.679 & .362 & 2.049 & .152 \\
\hline & Farmer\# & 0.000 & 1.000 & & & \\
\hline
\end{tabular}

\# = Reference category

This agrees with Sonsri (2007) who notes that in the urban setting (Bangkonk) in Thailand, it is easier for people to cohabit because it removes the pressure of marriage and sex from parents. The same in the American and European societies, cohabitation is either a prelude to marriage or an alternative lifestyle. Furthermore, most couples still wish to have marriage afterwards, which means that they do not necessarily reject marriage as a social institution.

The results also indicate that tribe was a significant factor in influencing cohabitation. The Baganda showed the highest level of co-habitation. They were 5 times $(O R=4.9)$ more likely to practice cohabitation than the Bafumbira (reference category) with a $p=0.000$. The Lugbara were 3 times $(O R=$ 3.I, $p=0.000$ ) and the Bagisu slightly less than 3 times $(O R=2.7, p=0.003)$ more likely to practice cohabitation than the Bafumbira. This shows that the Baganda are the most affected by cohabitation perhaps because of being the most urbanized tribe in Uganda. Tumwine (2007) noted that cohabitation was a common practice that the Baganda respondents were not comfortable with. One Focus Group described it as "an illegal marriage done in hiding. The whole thing is like prostitution". Another group commented that "cohabitation is a secret marriage without proper child bearing that leads to instability in marriage. The husband comes and goes away and the children may not be sure of the actual father. A woman may be called a prostitute "malaya" after cohabiting with many men".

\section{Secret marriages}

Secret marriage is a type of marriage that is kept unknown or hidden from family and friends. Secret marriages occur without the sanction of families or religious institutions and are between the two individuals. Therefore, they lack total commitment of the individuals involved and are more likely to deviate them from the "zero grazing" where sex involves only the known sexual partners. This type of marriage has had underlying implications especially with the rate at which urbanization is taking place in Uganda.

It could encourage the spread of sexually transmitted diseases including HIV/ AIDs (Tumwine and Sengendo, 2015).

Table 5 reveals that urban respondents were more involved in secret marriages (11.5\%) than their rural counterparts $(6.3 \%)$. This was because people in urban areas are individualistic and therefore more likely for men to keep 'outside wives' without being known by their partners (Tumwine and Sengendo, 2015). The Chi-square test established a strong association between secret marriages and area of residence. It was observed that area of residence was significantly associated with secret marriages $(p=$ $0.002)$ for both sexes and $(p=0.001)$ for females only.

Table 5: Secret marriages according to sex and area of residence

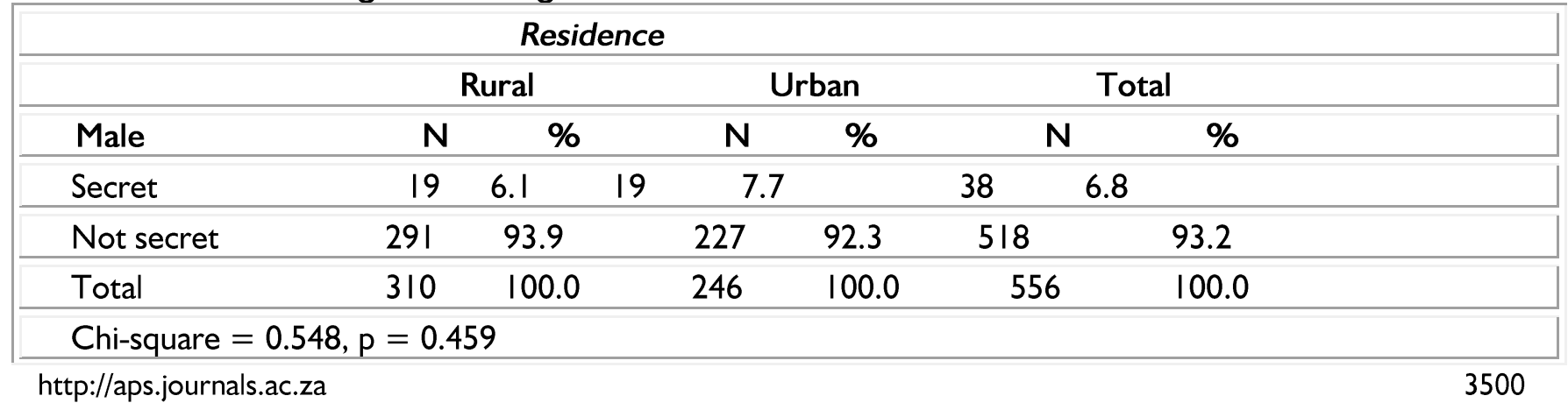




\begin{tabular}{|c|c|c|c|c|c|c|}
\hline \multicolumn{7}{|l|}{ Females } \\
\hline Secret & 18 & 6.5 & 37 & 15.4 & 55 & 10.6 \\
\hline Not secret & 261 & 93.5 & 203 & 84.6 & 464 & 89.4 \\
\hline Total & 279 & 100.0 & 240100.0 & 519 & & \\
\hline \multicolumn{7}{|c|}{ Chi-square $=10.945, p=0.001$} \\
\hline \multicolumn{7}{|c|}{ Both sexes } \\
\hline Secret & 37 & 6.3 & 5611.5 & 93 & & \\
\hline Not secret & 552 & 93.7 & 43088.5 & 982 & & \\
\hline Total & 589 & 100.0 & 486100.0 & 1075 & & \\
\hline \multicolumn{7}{|c|}{ Chi-square $=9.255, p=0.002$} \\
\hline
\end{tabular}

To establish the effect of selected factors on secret and declared types of marriage binary logistic regression was applied by making value I represent secret marriage and value 0 for declared marriages, which makes the dependent variable dichotomous. The results are summarized in Table 6. Residence is the second most significant factor in influencing secret and declared types of marriage. Logistic analysis revealed that residents in urban areas were 2 times $(\mathrm{OR}=1.7)$ more likely to be in secret marriages than those in rural areas. The main cause of secret marriages was probably poverty, which encouraged co-habitation. This is more so in urban areas where "cash economy" prevails. This agrees with Tumwine and Sengendo (2015) who observed that the secretive couples could not afford the lengthy process of introduction (“okwanjura"). This was especially true among the Baganda and more so in the urban area. The majority of the urban population $(80 \%)$ is classified as poor or low income earners and lack access to adequate housing infrastructure. Over $60 \%$ of the residents in urban areas stay in slums.

Tribe was found to be the most significant factor in affecting secret and declared types of marriage. The Baganda were found to be the most prone to secret marriages as they were almost 5 times $(O R=$ 4.6, $p=0.000)$, followed by Bagisu 4 times $(O R=$ 3.7, $p=0.001$ ) more likely to be in secret marriages than the Lugbara (reference category). Although the Bafumbira were almost 2 times $(O R=1.7)$ in secret marriages than the Lugbara, they were not significantly different $(p=.208)$.

Table 6: Results of binary Logistic regression analysis of selected variables of secret type of marriage

\begin{tabular}{|c|c|c|c|c|c|c|}
\hline \multicolumn{2}{|l|}{ Variables } & \multirow{2}{*}{\begin{tabular}{|l|} 
B \\
-4.138 \\
\end{tabular}} & \multirow[t]{2}{*}{$\begin{array}{l}\text { Odds } \\
\text { Ratios }\end{array}$} & \multirow{2}{*}{$\begin{array}{l}\text { Std. error } \\
.635\end{array}$} & \multirow{2}{*}{$\begin{array}{l}\text { Wald } \\
42.445\end{array}$} & \multirow{2}{*}{\begin{tabular}{|l|} 
P-value \\
.000 \\
\end{tabular}} \\
\hline & Intercept & & & & & \\
\hline \multirow[t]{2}{*}{ Residence } & Urban & .536 & 1.710 & .297 & 3.270 & .071 \\
\hline & Rural & 0.000 & 1.000 & & & \\
\hline \multirow[t]{3}{*}{ Religion } & Catholic & .168 & 1.183 & .383 & .192 & .661 \\
\hline & Protestant & .110 & 1.117 & .379 & .085 & .771 \\
\hline & Moslem \# & 0.000 & 1.000 & & & \\
\hline \multirow[t]{4}{*}{ Education } & None & .440 & 1.553 & .562 & .614 & .433 \\
\hline & Primary & .148 & 1.160 & .413 & .128 & .720 \\
\hline & Secondary & .501 & 1.650 & .381 & 1.731 & .188 \\
\hline & Tertiary \# & 0.000 & 1.000 & & & \\
\hline \multirow[t]{4}{*}{ Tribe } & Baganda & 1.518 & 4.561 & .358 & 17.990 & .000 \\
\hline & Bafumbira & .505 & 1.656 & .401 & 1.585 & .208 \\
\hline & Bagisu & 1.314 & 3.720 & .384 & II.692 & .001 \\
\hline & Lugbara \# & 0.000 & 1.000 & & & \\
\hline
\end{tabular}




\begin{tabular}{|l|l|l|l|l|l|l|}
\hline Occupation & Professionals & .161 & 1.175 & .445 & .131 & .717 \\
\hline & Other & .297 & 1.346 & .373 & .635 & .426 \\
\hline & Trader & .483 & 1.621 & .414 & 1.361 & .243 \\
\hline & Student & 2.117 & 8.309 & .988 & 4.595 & .032 \\
\hline & Farmer \# & 0.000 & 1.000 & & & \\
\hline
\end{tabular}

\# = Reference category

Uganda's diverse cultures and social settings have influenced family formation for a long time, with most societies having extended families. There are mutual obligations between all members of extended family, like parents bringing up all children in extended family especially in the rural areas (Tumwine, 2007). This is in tandem with Sonsri (2007) who noted that secret marriages in Thailand were as a result of the complicated nature of societies. There are traditions and social norms that need to be followed such as dowry money and big wedding ceremony.

Although urbanization has not been found by this study to be significantly related to secret marriages $(p=0.07 \mathrm{I})$ other studies have found contrary results. For example, Tumwine and Sengendo (2015) established that there is a relationship between secret marriages and the prevalence of HIV/AIDS and that urban informant were more involved in secret marriages (II.5\%) than their rural counterparts (6.3\%).
Polygamous versus monogamous type of marriage The extent of polygyny was measured by asking the married respondents how many co-wives or wives they had. The proportion of married respondents who were in polygynous unions according to residence is given in Table 7. Polygyny is higher in rural areas (19.8\%) than urban areas (10.2\%) because in the former, the economy is agricultural based which requires a lot of labor. It is interesting to note however, that the proportion of males reporting themselves as living in polygamous unions is lower (I3.9\%) than among females (16.8\%) (Tumwine and Nyakaana, 2010). The Chi-square test was carried out to establish whether associations exist between monogamous and polygamous types of marriage and area of residence. It was observed that area of residence was significantly associated with monogamy and polygamy.

Table 7: Monogamous and polygamous marriages by the respondents according to sex and type of place of residence.

\begin{tabular}{|c|c|c|c|c|c|c|}
\hline \multirow[b]{3}{*}{ Male } & \multicolumn{4}{|c|}{ Residence } & \multirow{2}{*}{\multicolumn{2}{|c|}{ Total }} \\
\hline & \multicolumn{2}{|r|}{ Rural } & \multicolumn{2}{|c|}{ Urban } & & \\
\hline & $\mathbf{N}$ & $\%$ & $\mathbf{N}$ & $\%$ & $\mathbf{N}$ & $\%$ \\
\hline Monogamous & 262 & 84.5 & 23488.0 & 496 & 86.1 & \\
\hline Polygamous & 48 & 15.5 & 32 & 12.0 & 80 & 13.9 \\
\hline Total & 310 & 100.0 & 266100.0 & 576 & 100.0 & \\
\hline \multicolumn{7}{|c|}{ Chi-square $=1.428, p=0.232$} \\
\hline \multicolumn{7}{|c|}{ Female } \\
\hline Monogamous & 204 & 75.3 & 23191.7 & 435 & 83.2 & \\
\hline Polygamous & 67 & 24.7 & 21 & 8.3 & 88 & 16.8 \\
\hline Total & 271 & 100.0 & 252100.0 & 523 & 100.0 & \\
\hline \multicolumn{7}{|c|}{ Chi-square $=25.064, p=0.000$} \\
\hline \multicolumn{7}{|c|}{ Both sexes } \\
\hline Monogamous & 466 & 80.2 & 46589.8 & 931 & 84.7 & \\
\hline Polygamous & 115 & 19.8 & 53 & 10.2 & 168 & 15.3 \\
\hline Total & 581 & 100.0 & 518100.0 & 1099 & 100.0 & \\
\hline
\end{tabular}


In the regression model, monogamous marriages were assigned value I while polygamous marriages were given value 0 . It was found that area of residence was significantly related with monogamous and polygamous types of marriage (Table 8). Area of residence was the third most significant factor after tribe and religion. Urban residents were found to be 2 times $(O R=2.0)$ more likely to be in monogamous marriages than rural residents with $p=0.007$. This implies that urbanization discourages polygamy. Polygamy sexually satisfies the men because of having more than one wife at the expense of sexually starving the wives. Urbanization coupled with women emancipation will go a long way in reducing the incidence of polygamy (Tumwine and Nyakaana, 2010). Urbanization is associated with literacy, high income levels and aspirations for better living standards, which discourage large family sizes (Tumwine, 20I6). This finding agrees with Yasuko and Kao- lee (1997) who observed that proportions of polygamy were lower in urban than rural areas. In the four countries studied, polygamy $44 \%$ versus $50 \%$ in Senegal, $28 \%$ versus $33 \%$ in Ghana, $18 \%$ versus $24 \%$ in Kenya and $9 \%$ versus $18 \%$ in Zimbabwe in urban and rural areas respectively.

Table 8 shows that the Bafumbira were found to be most monogamous ( $O R=6.1, p=0.000$ ) followed by the Baganda $(O R=2.9, p=0.000)$ and Bagisu $(O R=2.4, p=0.00 I)$. This result agrees with the focus group finding where the Baganda informants indicated that polygamy was on a decline in Buganda.

Table 8: Results of binary Logistic regression analysis of selected variables on monogamous marriages

\begin{tabular}{|c|c|c|c|c|c|c|}
\hline \multicolumn{2}{|l|}{ Variables } & \multirow{2}{*}{\begin{tabular}{|l}
$\beta$ \\
-.678
\end{tabular}} & \multirow{2}{*}{$\begin{array}{l}\text { Odds } \\
\text { Ratios }\end{array}$} & \multirow{2}{*}{\begin{tabular}{|l} 
Std. Error \\
.392 \\
\end{tabular}} & \multirow{2}{*}{\begin{tabular}{|l|} 
Wald \\
2.988 \\
\end{tabular}} & \multirow{2}{*}{\begin{tabular}{|l|}
$\mathrm{p}$-value \\
.084 \\
\end{tabular}} \\
\hline & Intercept & & & & & \\
\hline \multirow[t]{2}{*}{ Residence } & Urban & .706 & 2.026 & .262 & 7.244 & .007 \\
\hline & Rural \# & 0.000 & 1.000 & & & \\
\hline \multirow[t]{3}{*}{ Religion } & Catholic & .569 & 1.766 & .290 & 3.844 & .050 \\
\hline & Protestant & 1.121 & 3.069 & .314 & 12.762 & .000 \\
\hline & Moslem \# & 0.000 & 1.000 & & & \\
\hline \multirow[t]{4}{*}{ Education } & Primary & .475 & 1.607 & .295 & 2.591 & .107 \\
\hline & Secondary & .687 & 1.987 & .345 & 3.969 & .046 \\
\hline & Tertiary & 1.088 & 2.969 & .481 & 5.121 & .024 \\
\hline & None \# & 0.000 & 1.000 & & & \\
\hline \multirow[t]{4}{*}{ Tribe } & Baganda & 1.055 & 2.871 & .264 & 15.903 & .000 \\
\hline & Bafumbira & 1.808 & 6.098 & .304 & 35.294 & .000 \\
\hline & Bagisu & .888 & 2.431 & .256 & 12.012 & .001 \\
\hline & Lugbara \# & 0.000 & 1.000 & & & \\
\hline \multirow[t]{4}{*}{ Occupation } & Professionals & .446 & 1.562 & .358 & 1.550 & .213 \\
\hline & Other & .218 & 1.243 & .298 & .535 & .465 \\
\hline & Trader & -.426 & .653 & .341 & 1.567 & .211 \\
\hline & Farmer \# & 0.000 & 1.000 & & & \\
\hline
\end{tabular}

\# = Reference category

\section{Inter-marriages}

Respondents were asked to mention whether their marriages were mixed depending on the difference in tribe, religion or race. Three categories of mixed marriages were identified as observed in Table 9. These included: inter-tribal, inter-denominational and both inter-tribal and inter-denominational. A total of
223 respondents (93 rural and 130 urban) representing $1 \mathrm{I} .2 \%$ were in mixed marriages. Intertribal mixed marriages were more common in urban areas $(9.4 \%)$ compared to $4.0 \%$ in rural areas. Overall, mixed marriages were higher in urban $(I 5.3 \%)$ than rural areas (II.2\%). Kampala city is cosmopolitan in character. It is a residence to people 
of different tribes from all over Uganda and the world at large and this might encourage intermarriages. For instance, for the period 1991-2002, the Central region experienced positive net in-migration flows due to the growing rate of urbanization (UNFPA, 2006).

Inter-denominational type of mixed marriage was found to be more common in rural areas $(6.5 \%)$ than in urban areas (3.4\%). Inter-tribal type of mixed marriage was found to be more dominant in urban $(9.4 \%)$ than rural areas (4.0\%). A higher level of intermarriage of both inter-tribal and interdenominational was found to be more common in urban $(2.5 \%)$ than in rural areas $(0.7 \%)$. Urban areas had $16.2 \%$ of female respondents in mixed marriages compared with $14.4 \%$ of the male counterpart.

Table 9: Mixed marriages of the respondents according to sex and type of place of residence.

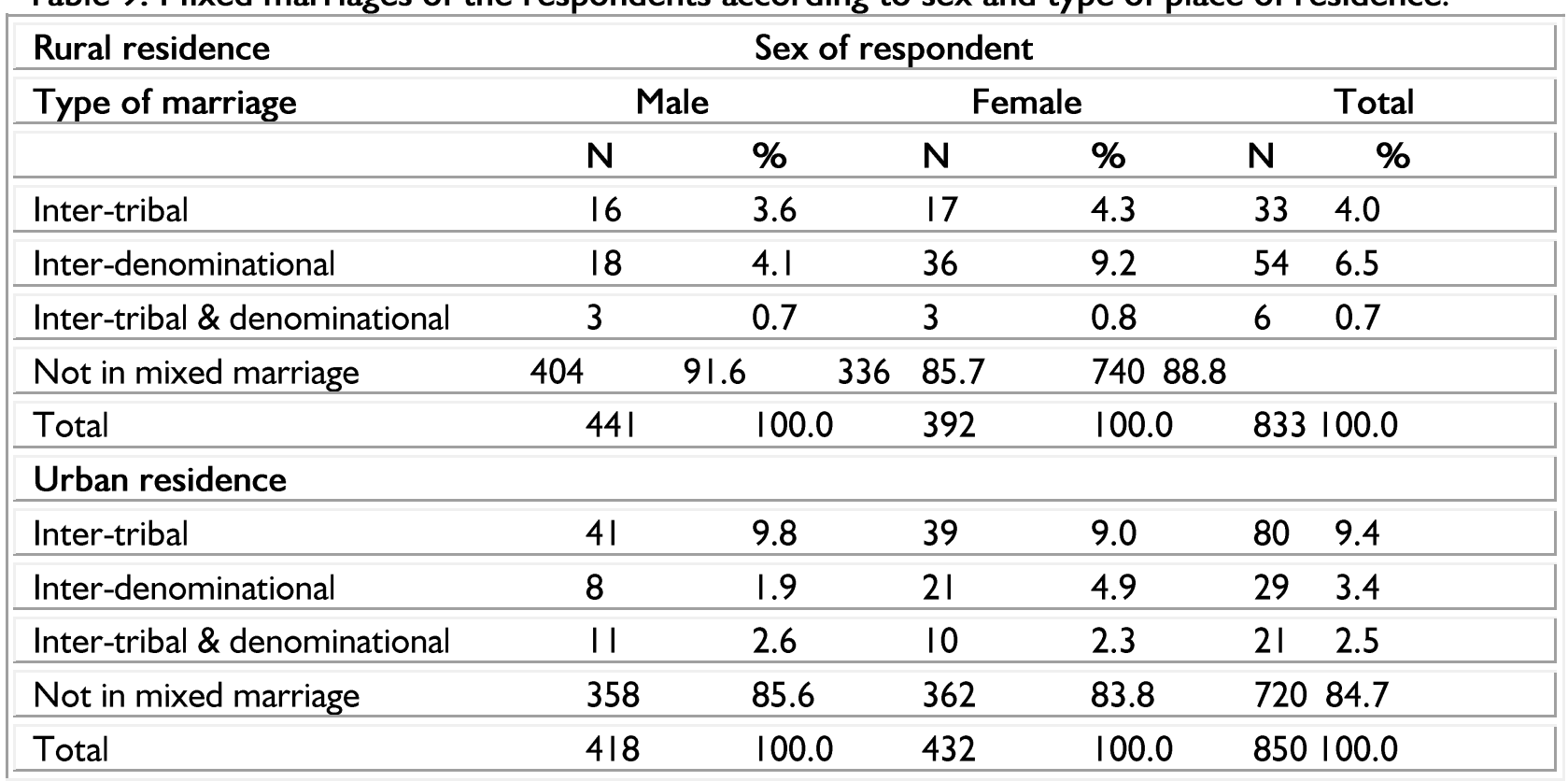

Logistic regression was also used to test the relationship between selected factors and intermarriage. In the model, mixed marriages were assigned $\mathrm{I}$ and non mixed 0 and Table 10 shows the summary of the results. The results show that tribe and occupation were the only significant factors of inter-marriage.

Tribe was a significant factor in influencing intermarriage. The Baganda were found to be 3 times
$(\mathrm{OR}=2.9, \mathrm{p}=0.000)$ more likely to intermarry than the Lugbara (reference category). Although the Bagisu and Bafumbira were not significant, they were found to have more odds of intermarriage, namely $\mathrm{I} .4$ times $(\mathrm{OR}=\mathrm{I} .4, \mathrm{p}=0.23 \mathrm{I})$ and $\mathrm{I} .3$ times $(\mathrm{OR}=$ I.3, $p=.360$ ) respectively than the Lugbara (reference category).

Table 10: Results of binary logistic regression analysis of selected variables on mixed marriage.

\begin{tabular}{|c|c|c|c|c|c|c|}
\hline \multicolumn{2}{|l|}{ Variables } & \multirow{2}{*}{\begin{tabular}{|l}
$\beta$ \\
-2.612 \\
\end{tabular}} & \multirow{2}{*}{$\begin{array}{l}\text { Odds } \\
\text { Ratios }\end{array}$} & \multirow{2}{*}{$\begin{array}{l}\text { Std. Error } \\
.407 \\
\end{array}$} & \multirow{2}{*}{$\begin{array}{l}\text { Wald } \\
41.237\end{array}$} & \multirow{2}{*}{$\begin{array}{l}\text { P value } \\
.000\end{array}$} \\
\hline & Intercept & & & & & \\
\hline \multirow[t]{2}{*}{ Residence } & Urban & .061 & 1.063 & .206 & .089 & .765 \\
\hline & Rural \# & 0.000 & 1.000 & & & \\
\hline \multirow[t]{3}{*}{ Religion } & Catholic & .031 & 1.031 & .268 & .013 & .909 \\
\hline & Protestant & -.069 & .933 & .267 & .067 & .795 \\
\hline & Moslem \# & 0.000 & 1.000 & . & . & . \\
\hline Education & Primary & .257 & 1.293 & .327 & .618 & .432 \\
\hline
\end{tabular}




\begin{tabular}{|l|l|l|l|l|l|l|}
\hline \multirow{5}{*}{} & Secondary & .546 & 1.726 & .352 & 2.403 & .121 \\
\cline { 2 - 8 } & Tertiary & .530 & 1.698 & .398 & 1.766 & .184 \\
\cline { 2 - 8 } & None \# & 0.000 & 1.000 &. &. &. \\
\hline \multirow{5}{*}{ Tribe } & Baganda & 1.054 & 2.869 & .227 & 21.503 & .000 \\
\cline { 2 - 8 } & Bafumbira & .228 & 1.256 & .249 & .837 & .360 \\
\hline \multirow{5}{*}{ Occupation } & Bagisu & .302 & 1.352 & .252 & 1.432 & .231 \\
\cline { 2 - 8 } & Lugbara \# & 0.000 & 1.000 &. &. &. \\
\hline & Professionals & .264 & 1.302 & .310 & .724 & .395 \\
\cline { 2 - 7 } & Other & .620 & 1.860 & .264 & 5.519 & .019 \\
\cline { 2 - 7 } & Trader & .363 & 1.438 & .307 & 1.404 & .236 \\
\hline & Student & 1.072 & 2.921 & .782 & 1.877 & .171 \\
\cline { 2 - 7 } & Farmer \# & 0.000 & 1.000 &. &. &. \\
\hline
\end{tabular}

\# = Reference category

The Baganda's highest chances of intermarriage are because they are indigenous in Kampala, the biggest urban area of Uganda and are inhabitants of the Central region which has for a long time experienced positive in-migration flows. This is confirmed by Ntozi et al (20II) who showed that between 1969 and 1991, in migration rates for four of the six districts with rates above 25 percent (Mubende 27.5, Mukono 27.6, Kalangala 40.0, and Kampala 57.7) were in central region. According to the 2002 Uganda Population and Housing Census, the central region had the biggest share $(57 \%)$ of internal inmigration (UBOS 2006). It has to be noted that some of the young in-migrants of other tribes could choose marriage partners from the Baganda tribe and therefore, increasing the number of intermarriages. In Brazil, racial intermarriages between blacks (preta), brown (panda) and whites were found to be more acceptable than was the case two decades before as shown by Mitchell et al (2010). The results show higher rates of intermarriage in urban than rural areas. This is attributed to the effects of industrialization, urbanization and education which jointly influence social values and patterns of human interaction. A prominent theme in Brazil: "money whitens" has emerged. This is in reference to educated blacks of slave origin acquiring wealth through good paying jobs marrying whites.

\section{Age at first marriage}

Age at marriage is one of the most important components of marriage patterns. Respondents were asked to give the age at which they first got married. Table II shows the mean age at first marriage by sex and residence. The table shows that rural respondents married at a slightly lower age of 21.7 than their urban counterparts who got married at 22.2 years.

Table II: Mean Age at marriage of the respondents according to sex and type of place of residence.

\begin{tabular}{|l|l|l|l|l|}
\hline Sex & Residence & Mean age & Number & $\%$ \\
\hline Male & Rural & 24.0 & 309 & 26.82 \\
\hline & Urban & 24.4 & 256 & 22.02 \\
\hline & Total & 24.2 & 565 & 48.09 \\
\hline Female & Rural & 19.3 & 302 & 26.01 \\
\hline & Urban & 20.1 & 288 & 24.09 \\
\hline & Total & 19.7 & 590 & 51.01 \\
\hline Total & Rural & 21.7 & 611 & 52.09 \\
\hline & Urban & 22.2 & 544 & 47.01 \\
\hline & Total & 21.9 & 1155 & 100.00 \\
\hline
\end{tabular}


As can be seen in Table 12, $42 \%$ of the rural respondents got married before age of 19 compared to $34 \%$ in the urban areas. The study revealed that a bigger proportion of respondents in urban areas $(66 \%)$ were married after 20 years in compared to $58 \%$ in rural areas.

Area of residence is statistically significant $(p=$ 0.002 ) for both males and females. The association is stronger for females $(p=0.00 \mathrm{I})$ than males $(p=$
0.043). This could be because urban residents, especially females have higher levels of education than their rural counterparts and education delays age at marriage. This concurs with The Uganda Population Report 2004, which shows that there are rural-urban differentials in literacy rates. The rates are higher in urban (87\%) than rural areas (67\%) (Tumwine, 2007).

Table 12: Age at marriage of the respondents according to sex and type of place of residence.

\begin{tabular}{|c|c|c|c|c|c|c|}
\hline \multicolumn{7}{|c|}{ Area of residence } \\
\hline Age at marriage & \multicolumn{2}{|c|}{ Rural } & \multicolumn{2}{|c|}{ Urban } & \multicolumn{2}{|r|}{ Total } \\
\hline \multicolumn{7}{|l|}{ Males } \\
\hline & $\mathbf{N}$ & $\%$ & $\mathbf{N}$ & $\%$ & $\mathbf{N}$ & $\%$ \\
\hline $10-19$ & 65 & 21.0 & 37 & 14.5 & 102 & 18.1 \\
\hline $20+$ & 244 & 79.0 & 219 & 85.5 & 463 & 81.9 \\
\hline Total & 309 & 100.0 & 256 & 100.0 & 565 & 100.0 \\
\hline \multicolumn{7}{|c|}{ Chi-square $=4.101, p=0.043$} \\
\hline \multicolumn{7}{|l|}{ Female } \\
\hline $10-19$ & 194 & 64.2 & 146 & 50.7 & 340 & 57.6 \\
\hline $20+$ & 108 & 35.8 & 142 & 49.3 & 250 & 42.4 \\
\hline Total & 302 & 100.0 & 288 & 100.0 & 590 & 100.0 \\
\hline \multicolumn{7}{|c|}{ Chi-square $=11.075, p=0.001$} \\
\hline \multicolumn{7}{|c|}{ Both sexes } \\
\hline $10-19$ & 259 & 42.4 & 183 & 33.6 & 42 & $2 \quad 38.3$ \\
\hline $20+$ & 352 & 57.6 & 361 & 64.4 & 713 & $\begin{array}{ll}3 & 61.7 \\
\end{array}$ \\
\hline Total & 611 & 100.0 & 544 & 100.0 & 115 & $5 \quad 100.0$ \\
\hline
\end{tabular}

In the regression model, age group 10-19 was assigned value I while $20+$ was given value 0 . This grouping was based on the fact that in Uganda, marriages occur early. For example, $56 \%$ of Ugandan women married before age 18 (Statistics Department MoFEP, 1996). Logistic regression was applied to understand the effect of the selected variables, area of residence inclusive, on age at first marriage. Table 13 shows the results. Although urban residents were only I.3 times $(O R=1.3, p=0.1$ I $)$ likely to marry earlier than those in rural areas, which makes urbanization not significant variable of age at first marriage, urbanization was related to some of the variables that are significant as seen below.

Table 13: Results of Logistic regression of selected variables on age at first marriage

\begin{tabular}{|l|l|l|l|l|l|l|}
\hline Age at marriage: 10-19 & & B & Odds ratios & $\begin{array}{l}\text { Std. } \\
\text { Error }\end{array}$ & Wald & p-value \\
\hline & Intercept & -6.996 & & .809 & 74.710 & .000 \\
\hline \multirow{3}{*}{ Residence } & Urban & .281 & 1.324 & .175 & 2.557 & .110 \\
\hline & Rural \# & 0 & 1.000 &. &. &. \\
\hline \multirow{2}{*}{ Religion } & Catholic & .123 & 1.131 & .140 & .769 & .380 \\
\cline { 2 - 8 } & Moslem & .257 & 1.293 & .222 & 1.343 & .247 \\
\cline { 2 - 8 } & Protestant \# & 0 & 1.000 &. &. &. \\
\hline
\end{tabular}




\begin{tabular}{|l|l|l|l|l|l|l|}
\hline Education & None & 3.029 & 20.685 & .406 & 55.684 & .000 \\
\cline { 2 - 7 } & Primary & 2.322 & 10.196 & .373 & 38.823 & .000 \\
\hline & Secondary & 1.518 & 4.563 & .372 & 16.637 & .000 \\
\hline & Tertiary \# & 0 & 1.000 &. &. &. \\
\hline Tribe & Baganda & 1.273 & 3.571 & .205 & 38.473 & .000 \\
\hline & Bafumbira & .417 & 1.517 & .209 & 3.987 & .046 \\
\hline & Lugbara & .924 & 2.519 & .206 & 20.104 & .000 \\
\hline & Bagisu \# & 0 &. &. &. &. \\
\hline Occupation & Professionals & 2.661 & 14.304 & .750 & 12.587 & .000 \\
\cline { 2 - 7 } & Farmer & 3.548 & 34.737 & .731 & 23.532 & .000 \\
\hline & Other & 3.154 & 23.429 & .724 & 18.977 & .000 \\
\hline & Trader & 3.003 & 20.148 & .736 & 16.659 & .000 \\
\hline & Student \# & 0 & 1.000 &. &. &. \\
\hline
\end{tabular}

\section{$\#=$ Reference category}

For instance, it has been found that education is the most significant factor in affecting age at first marriage. The results show that the lower the level of education, the higher the chances of marrying earlier. Table 13 shows that respondents with no education were 21 times $(O R=20.7, p=0.000)$ more likely to marry earlier than those with tertiary education (reference category). Those with primary education were 10 times $(O R=10.2, p=0.000)$ and those with secondary education 5 times $(O R=4.6$, $p=0.000$ ) more likely to marry earlier than those with tertiary education. Therefore, it can be inferred that urbanization operates indirectly through education to affect age at first marriage. This concurs with studies elsewhere. For example Jones (2010) observes trends towards later and less marriage throughout Asia particularly marked in East and South East Asia especially in large cities of the region and among highly educated women. Rutaremwa (2016) further observes that age at marriage has been increasing since 1969 for both males and females but that this is more so for males. While the early age at which women marry could be attributed to culture, men on the other hand are expected to obtain employment in order to afford bride wealth.

Tribe was also related with age at first marriage because the Baganda were 4 times $(O R=3.6,0.000)$ more likely to marry earlier than the Bagisu (reference category). The Lugbara were almost 3 times $(O R=2.5, p=0.000)$ and the Bafumbira, almost 2 times $(O R=1.5, p=0.046)$ more likely to marry earlier than the Bagisu. These results are

unexpected because Baganda who are more urbanized are expected to marry later than other 3507 tribes. May be the findings have something to do with the cultures of these tribes. For instance, the area of study in Buganda has many Moslems who tend to marry young, compared with other tribes who are more Christian.

\section{Conclusion and recommendations}

Despite the regular collection of demographic data in Uganda, little has been done in studying nuptiality patterns. Perhaps this has been due to the fact that most data include only a simple question on marital status of the respondents (Rutaremwa, 2016). This study utilizes survey data collected from the four regions of Uganda using a detailed questionnaire and other secondary sources to reflect on the influence of urbanization on marriage practices and patterns of the Baganda in Uganda.

The paper reveals an increase in age at marriage, more secret marriages, divorce cases and cohabitation among the Baganda in the urban areas compared to rural areas. Having noted that reduction of poverty should emanate from the family level, multidimensional urban planning should be the leading approach in all urban areas of Uganda in order to improve the living conditions of the urban residents and reduce the negative implications of secret marriages, divorce cases and cohabitation. Increasing age at marriage will go a long way in reducing fertility thereby reducing the high population growth rate ((3.03\% per annum (UBOS, 20I4)) and youth bulge (Rutaremwa, 2016), both of which will retard the 2030 Sustainable Development Goals (SDGs) of the country.

The authors recommend that traditional leaders, religious leaders in conjunction with the ministry of Gender, Labour and Social Development should http://aps.journals.ac.za 
discourage parents from asking for expensive items and exorbitant sums of money for bride price in order to encourage religious and civil marriages while discouraging cohabitation, secret marriages and prostitution.

The Queen mother "Nabagereka" should be encouraged and supported by Buganda Kingdom and the Central Government of Uganda to continue with her all round teaching and instructions "ebisagate" to children of different ages. This is because, "pulling" as one of the cultural practices cherished by the Baganda is one of the items taught to the girls. In the same vein, the instructions by the Queen mother should include the male children as well. This is because it has been observed boys are not at the same level with the girls in nuptiality issues.

\section{References}

Byamukama, D.C.K. (2006) "Is your marriage legally recognized?" New Vision, Tuesday, September $12^{\text {th }}, 2006$

Ekibiina Ky'olulimi Oluganda (199I) Kabbokamuwala M.K General School Supplies Ltd.

Etyang, J. and Natukunda, C. (2005) "Visiting the bush linked to HIV" The New Vision, Tuesday, August $16^{\text {th }}, 2005$

Jones, G. (2010) Changing marriage patterns in Asia. Asia Research Institute working paper No.131, Jan. 152010.

Hajnal, J. (1953) "Age at marriage and proportion marrying” Population studies.Vol 7, No. 2 pp I I I136.

Kitchin, Rand Tate, N (2000) Conducting Research into Human Geography: Theory, methodology and practice.Pearson Education. Inc., New Jeersy.

Lamptey, P.R., Jami, L.J. and Khan, M. (2006) "The Global Challenge of HIV and AIDS". Population Bulletin.Vol.6I, No.l. A publication of the Population Reference Bureau.

Makinwa- Adebusoye, Paulina (200I) "Sociocultural factors affecting fertility in sub-Saharan Africa". The Nigerian Institute of Social and Economic Research (NISER) Lagos.

Ministry of Finance and Economic Planning (Oct. 1992) The 1991 Population and Housing Census, Kampala district.Statistics Division Ministry of Planning and Economic Development, Entebbe, Uganda.

Ministry of Finance and Economic Planning, Statistics Department (August 1996) Uganda Demographic and Health Survey 1995. Macro International Inc, Calverton, Maryland USA.

Ministry of Finance and Economic Planning (2005) 2002 Uganda Population and Housing Census.Uganda Bureau of Statistics, Entebbe, Uganda.
Mitchell Colter, Xuaning Fu, Heaton B. Tim and Cardell Jacobson (2010) Urbanization, education and racial intermarriage in Brazil.

Nagawa Fortunate (2015) "Omusajja akyazaabakazi mu nsiko atabudde ekibuga" Bukedde News Paper, Wednesday, November II 2015.

Ntozi J, Nzabona A and Tumwine F (20lI) "Evolution of internal migration in Uganda since the 1950s" MIGRATION in the service of African development. Essays in honour of Professor AderantAdepoju pp 342-360 Safari Books Ltd Cmbridge House 20 JoopBerkhout Crescent Onireke, Ibadan

Nzita, R. and Mbaga-Niwampa (1997) Peoples and cultures of Uganda. Fountain Publishers Ltd.

Rutaremwa Gideon (2016) "Nuptiality patterns and differentials in Uganda since the 1960s: Evidence from Census and Survey Cross-sectional Data" The Demography of Uganda and selected African Countries. Towards more Sustainable Development Pathways. Scholary Works Dedicated to Professor James Patrick Ntozi. Fountain Publishers.

Statistics Department Ministry of Finance and Economic Planning (1996) Uganda Demographic and Health Suuvey, 1995. Macro International Inc,-Calverton, Maryland USA.

Sonsri Samart (2007) Unmarried cohabitation in Thailand. The case of migrant workers in Bangkok.

Tumwine Fredrick and Mwebaze Tom (2016) "Impact of population Growth on Poverty Reduction in Uganda" The Demography of Uganda and selected African Countries. Towards more Sustainable Development Pathways. Scholary Works Dedicated to Professor James Patrick Ntozi. Fountain Publishers.

Tumwine Ruguma Fredrick (2016) "Population and Disaster Vulnerability in Uganda"

Disasters and Climate Resilience in Uganda: Processes, Kowledge and Practices.

Tumwine Fredrick Ruguma (2015) "Changes in marriage practices among the Bafumbira of Western Uganda".Journal of Geography and Regional Planning. Vol. 8 (2), pp. 16-25.

Tumwine Fredrick and Sengendo Hannington (2015) "Urbanization and HIV/AIDs in Uganda with reference to secret marriages" The African Resources Journal Vol. I, issue No. 2, March 20I5, pp 33-44

Tumwine Fredrick Ruguma and Ahebwa Wilber Manyisa (20/2) "Implications of rapid population growth on sustainable tourism development in Uganda" MAWAZO The journal of Faculty of Arts and Social Sciences, Makerere University, Vol. II, No. 2, pp I02-I I 5 June 2012. 
Tumwine Fredrick and Nyakaana Baker (2010) "Urbanization and polygamy in Uganda: implications for poverty reduction"MAWAZO The journal of Faculty of Arts and Social Sciences, Makerere University, Vol. 9, No I, February 20I0, Pp 102-II5

Tumwine Fredrick Ruguma (2007) The Impact of urbanization on marriage patterns in lake victoria crescent. Unpublished $\mathrm{PhD}$ thesis.

UBOS (2006) 2002 Uganda Population and Housing Census. Analytical Report. Abridged Version.
UBOS (2014) National Population and Housing Census 2014 Provisional results. November 2014. Revised Edition.

UNFPA (2007) State of Uganda Population Report 2007.Planned Urbanization for Uganda's Growing Population.

Yasuko Hayase and Kao- Lee Liw (1997) Factors on polygamy in sub-Saharan Africa: Findings based on Demographic and Health Surveys. The Developing Economies XXXV-3 September 19997: 293-327.

Zeiten K. Miriam (2008) Polygamy: A cross cultural analysis. 